\title{
Pro a předem prohraný souboj proti PCSK9 inhibitorům
}

Sympozium společnosti Sanofi na XXIX. výročním sjezdu České kardiologické společnosti, které proběhlo 21. 5. 2021, bylo věnováno praktickému využití inhibitorů PCSK9 (PCSK9i) v léčbě dyslipidemie u pacientů s vysokým a velmi vysokým kardiovaskulárním (KV) rizikem. Šest předních českých kardiologů rozebralo 3 kazuistiky, na kterých prezentovali prínos alirocumabu u pacienta s familiární hypercholesterolemií (FH), pacienta po akutním koronárním syndromu (AKS) a pacientky s ischemickou chorobou srdeční (ICHS) bez možnosti revaskularizace, u nichž využili alirocumab k potřebnému výraznému snížení LDL cholesterolu k cílovým hladinám. Vysvětlili, že u pacientů s intenzivní statinovou léčbou, kteří mají stále více než dvojnásobek cílové hladiny LDL cholesterolu, je přidání PCSK9i jedinou cestou, jak požadovaného poklesu dosáhnout, protože přidání ezetimibu tak výrazný efekt nemá. Vzhledem k tomu, že úhradová kritéria tento postup umožňují, pokud je medicínsky odůvodněný, lze využít PCSK9i k přínivému ovlivnění prognózy nemocných doloženému významným snížením rizika KV príhod a celkové mortality.

\section{Jak ovlivnit osud pacientů s vysokým $\mathrm{KV}$ rizikem?}

Dnes máme po dlouhých letech k dispozici nástroje pro účinnou léčbu pacientů s vysokým KV rizikem v primární i sekundární prevenci. Aterosklerózu již můžeme považovat za v zásadě vyléčitelné onemocnění, a máme tak přiležitost dále snižovat KV mortalitu. Jsme ale skutečně schopni zachytit a léčit většinu pacientů s vysokým KV rizikem, děláme pro to dostatek, využíváme mezioborové spolupráce a příznivých indikačních kritérií PCSK9i?

\section{Jsou vzácné dyslipidemie v kardiologii opravdu vzácné?}

Kazuistika 1: pacient s hereditární familiární hypercholesterolemií - úvod

prof. MUDr. Vladimír Blaha, CSc.

(Klinika gerontologická a metabolická LF UK

a FN Hradec Králové)

47letý muž, povoláním zahradník, se v roce 2003 dostavil na vyšetření z důvodu př́znaků námahové anginy pectoris. Pacient byl obézní, při vyšetření u něj byl zjištěn diabetes 2. typu, hladina celkového cholesterolu (TC) 9,95 mmol/I, LDL cholesterolu (LDL-c) 6,29 mmol/I, HDL cholesterolu (HDL-c) $1,08 \mathrm{mmol} / \mathrm{I}$ a triglyceridů (TG) $17,9 \mathrm{mmol} / \mathrm{l}$. Uvedl, že se ve věku 15-25 let léčil pro hypercholesterolemii, ovšem po konfliktu s lékařem přestal léčbu užívat. Vzhledem ke koronarografickému nálezu, který ukázal postižení všech 3 tepen byla indikována implantace bypassu (CABG). Poté byl pacientovi nasazen simvastatin v dávce $40 \mathrm{mg}$ denně. Lipidogram se mírně zlepšil: hladina TC činila 8,96 mmol/I, LDL-c 6,7 mmol// a TG 2,97 mmol/l. Genetické vyšetření prokázalo mutaci S285X genu pro LDL receptor a byla potvrzena heterozygotní familiární hypercholesterolemie. Vzhledem k neuspokojivé kompenzaci dyslipidemie byla v roce 2005 léčba změněna na atorvastatin 80 mg denně. Dosažená úprava lipidogramu
(TC 7,98 mmol/I, LDL-c 5,26 mmol/I, TG 4,68 mmol/l) byla stále nedostatečná. K terapii byla proto přidána LDL aferéza (extrakorporální eliminace LDL-c) a ezetimib v dávce $10 \mathrm{mg}$ denně. Hladina TC klesla na 5,13 mmol//, LDL-c na 3,56 mmol/I a TG na 2,03 mmol/I. HDL-c činil 1,07 mmol/l a pacient byl bez symptomů KV onemocnění. $V$ té době se jednalo o maximální možnou terapii a dosažitelnou úpravu dyslipidemie.

\section{Co znamenají PCSK9 inhibitory pro pacienty s familiární hypercholesterolemií? prof. MUDr. Michal Vrablík, Ph.D. \\ (Centrum preventivní kardiologie, \\ III. interní klinika 1. LF UK a VFN, Praha)}

Familiární hypercholesterolemie (FH) je primární monogenní porucha s autosomálně dominantní dědičností a frekvencí výskytu 1:200. Jde o nejčastější dědičné metabolické onemocnění, které se projevuje zvýšenou hladinou LDL-c, předčasnou manifestací aterosklerózy a šlachovými xantomy (1). Před zavedením PCSK9i nebylo možné u těchto pacientů dosáhnout cílových hodnot lipidů.

O prítomnosti FH je třeba uvažovat u osob s hladinou LDL-c $>5 \mathrm{mmol} / \mathrm{I}$ zjištěnou nejméně při 2 měřeních. Hladiny HDL-c a TG bývají u FH obvykle $\checkmark$ normě. Při klinickém vyšetření můžeme nalézt šlachové xantomy, arcus lipoides a xantelesmata, $v$ rodinné anamnéze zjištujeme ICHS nebo LDL-c > 5 mmol/I, v osobní anamnéze predčasnou ICHS, cévní mozkovou př́hodu (CMP) nebo jiné aterosklerotické onemocnění. Muži s FH mají již ve věku 50 let 45\% pravděpodobnost ICHS a 25\% pravděpodobnost infarktu myokardu (IM), u žen je 45\% riziko ICHS a 15\% riziko IM prítomno ve věku 60 let (2). Až 20\% pacientů s FH utrpí IM do 35 let věku (3). Prítomnost mutace podmiňující FH znamená vždy násobně vyšší riziko ICHS v porovnání s osobami bez FH se stejnou hladinou LDL-c (obr. 1) (4). Tento jev je vysvětlitelný faktorem času, tedy dlouhodobým působením zvýšené hladiny LDL-c. 


\section{| NOVINKY V KARDIOLOGII}

Obr. 1. Prítomnost mutace podmiňujicí familiární hypercholesterolemii (FH) znamená vždy násobně vyšší riziko ischemické choroby srdeční v porovnáni sosobami bez FH se stejnou hladinou LDL cholesterolu (4)

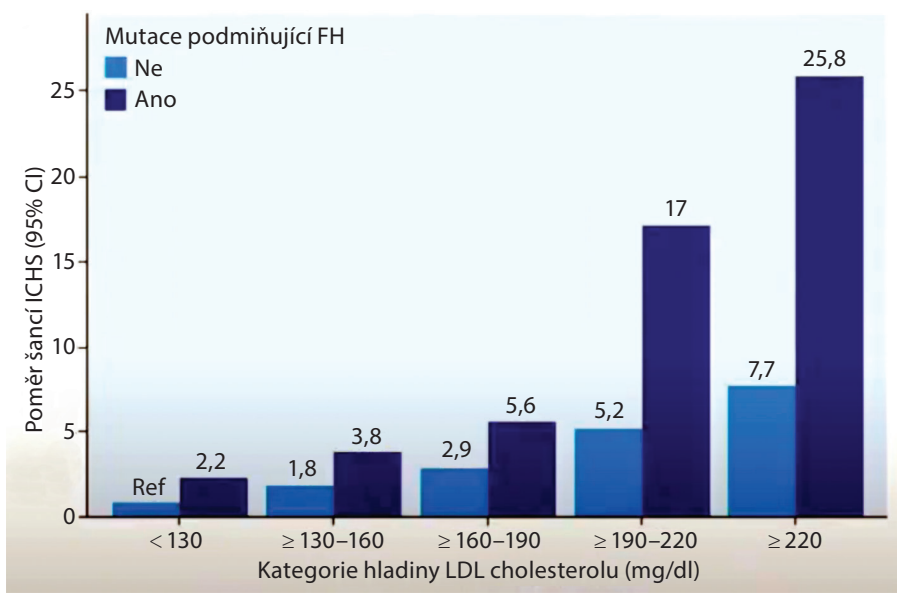

Nemocní s FH spadají vždy do kategorie vysokého KV rizika, a pokud mají aterosklerotické KV onemocnění nebo další KV rizikový faktor, jedná se již o velmi vysoké KV riziko. Před dostupností PCSK9i dosahovalo v projektu PLANET (6) provedeném ve specializovaných centrech cílových hodnot LDL-c $<2,5 \mathrm{mmol} / \mathrm{I}$ pouze 15,4\% pacientů s FH. Při léčbě PCSK9i (evolocumabem i či alirocumabem) dosahují cílové hodnoty LDL-c $<1,8 \mathrm{mmol} / /$ zhruba 2/3 pacientů $(7,8)$. A této cílové hodnoty LDL-c Ize s PCSK9i dosáhnout i u nemocných s FH s nejtěžším lipoproteinovým fenotypem (9). Účelem léčby hypercholesterolemie ovšem není snížení hladiny LDL-c, ale zlepšení jejich prognózy. Alirocumab prídaný k intenzivní statinové terapii snižil v placebem kontrolované studii ODYSSEY OUTCOMES u pacientů po AKS celkovou mortalitu během 4 let o $15 \%(H R=0,85,95 \% \mathrm{Cl} 0,73-0,98, p=0,025)$, (obr. 2) (9).

Alirocumab (Praluent ${ }^{\oplus}$, Sanofi) je dnes nově k dispozici nejen pro dávkování 75 a 150mg 1× za 14 dní, ale také v předplněném peru s dávkou 300 mg, která se podává 1× za 4 týdny. Nedávno byly změněny podmínky úhrady pro alirocumab i evolocumab, které jsou nyní jednotně hrazeny u pacientů s adherencí k dietním opatřením a hypolipidemické léčbě s heterozygotní FH nebo nefamiliární hypercholesterolemií či smíšenou dyslipidemií ve velmi vysokém KV riziku s manifestním KV onemocněním, u nichž není stávající vysoce intenzivní hypolipidemická léčba dostatečně účinná pro dosažení hladiny $L D L-c \leq 3,1$ mmol/I u heterozygotní FH či $\leq 2,5 \mathrm{mmol} / \mathrm{l}$ v ostatních prípadech. Tato kritéria platí i u pacientů s prokazatelnou kontraindikací nebo intolerancí statinů.

\section{Proč nedat PCSK9i nemocnému po akutním koronárním syndromu? prof. MUDr. Richard Češka, CSc. (Centrum preventivní kardiologie, III. interní klinika 1. LF UK a VFN, Praha)}

Odpověd' na tuto otázku se nehledá snadno. Jedním z možných argumentů může být cena, ta ale nepřesahuje 100000 Kč/rok a odpovídá zhruba ceně za moderní léčbu diabetu.

Dalším důvodem, proč léčbu PCSK9i lékaři nezvažují, může být omezení preskripce na specializovaná centra. Těchto center je ale v ČR přes 20 a jejich rozložení po republice je rovnoměrné.
Obr. 2. Alirocumab prìdaný k intenzivní statinové léčbě snižuje u pacientů po akutní koronární príhodě celkovou mortalitu (9)

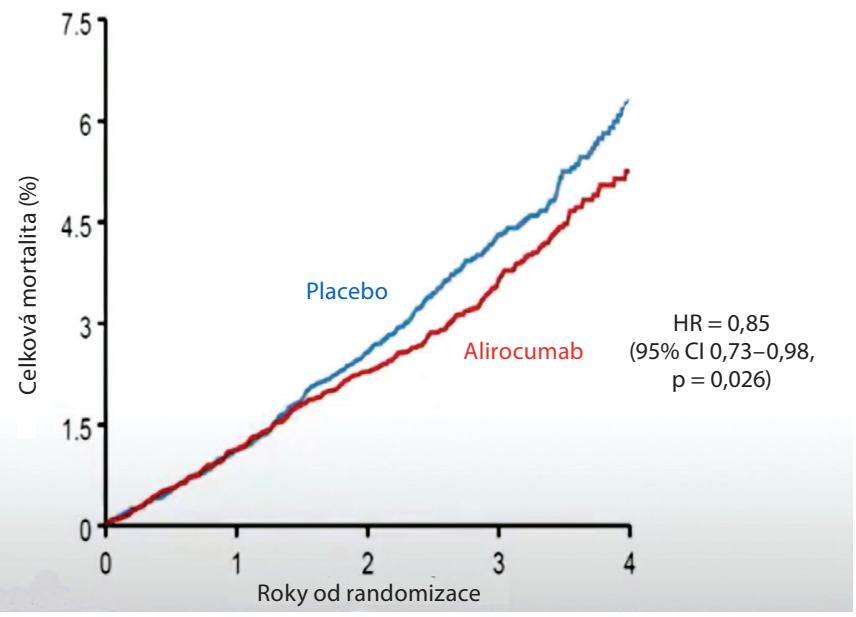

Váhání s léčbou PCSK9i může být dáno možnými obavy vyplývajícími z pozorované spojitosti nádorových onemocnění a nízké hladiny cholesterolu. V rámci této souvislosti ale není hypocholesterolemie príčinou, ale důsledkem nádorového onemocnění vznikajícím z důvodu katabolických procesů a kachektizace.

Rovněž prì pozorované souvislosti mezi nízkou hladinou cholesterolu a těžším průběhem infekce covid-19 je hypocholesterolemie důsledkem, nikoliv př́činou těžké infekce. Cholesterol v buněčných membránách je (kromě interakce s ACE2 receptorem) nezbytný pro proniknutí SARS-CoV-2 do buněk. V reakci na infekci buňka snižuje produkci cholesterolu, což je klinicky známý efekt. Bylo zjištěno, že pacienti léčení statiny mají nižší riziko těžkého průběhu covidu-19 a nižší mortalitu na toto onemocnění $(10,11)$. To může být dáno protizánětlivým působením statinů nebo prímým ochranným účinkem hypocholesterolemie. Snížení LDL-c Ize považovat za ochranu proti průniku infekce do buněk. U pacientů s covidem-19 je proto doporučeno pokračovat v podávání PCSK9i ve stejném dávkovacím intervalu. Změna dávkovacího intervalu této léčby není na místě ani při očkování proti covidu-19, pouze platí, že by se PCSK9i neměl aplikovat $\checkmark$ den vakcinace a do stejné oblasti.

Dalším důvodem nepodávání PCSK9i může být samozřejmě nesplnění indikačních kritérií. Indikační kritéria již byla uvedena výše. Je třeba ovšem připomenout, že pokud je pacient s FH současně pacientem v sekundární KV prevenci, platí indikační kritéria pro sekundární prevenci.

Kazuistika 2: pacient s akutním koronárním syndromem - úvod

\section{MUDr. Jiří Veselý \\ Kardiologická ambulance Edumed}

V dubnu 2021 byl na vlastní žádost príijat do kardiologické péče 55letý muž po propuštění z nemocnice pro IM. Jeho otec zemřel v 59 letech na svůj druhý IM. Pacient v mládí kouřil, ale ve 27 letech přestal po smrti svého otce. Již 5 let je léčen pro hypertenzi perindoprilem v dávce $5 \mathrm{mg} / \mathrm{den}$ s dobrou kompenzací (dle domácího měření 135-140/90 mm Hg) a 2 roky pro dyslipidemii atorvastatinem $\vee$ dávce $10 \mathrm{mg} / \mathrm{den}$. Věnuje se rekreačnímu sportu. 
Obr. 3. Pokles hladiny LDL cholesterolu (LDL-c) u pacientů s vysokým kardiovaskulárním rizikem a nedostatečně kompenzovanou hypercholesterolemiípři pridání ezetimibu v porovnánís prìdáním alirocumabu kmaximální tolerované dávce statinu (studie ODYSSEY COMBO II) (15)

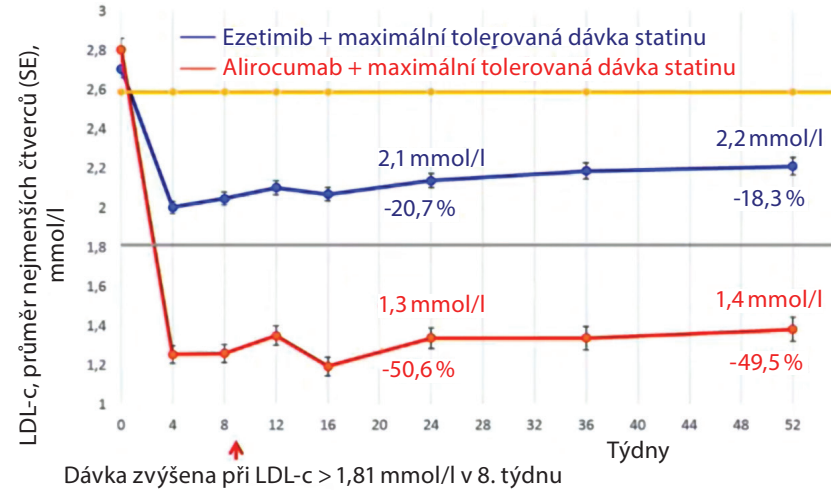

Obr. 4. Alirocumab pridaný k intenzivní statinové léčbě snižuje u pacientů po akutním koronárním syndromu riziko velkých kardiovaskulárních príhod (MACE) (26)

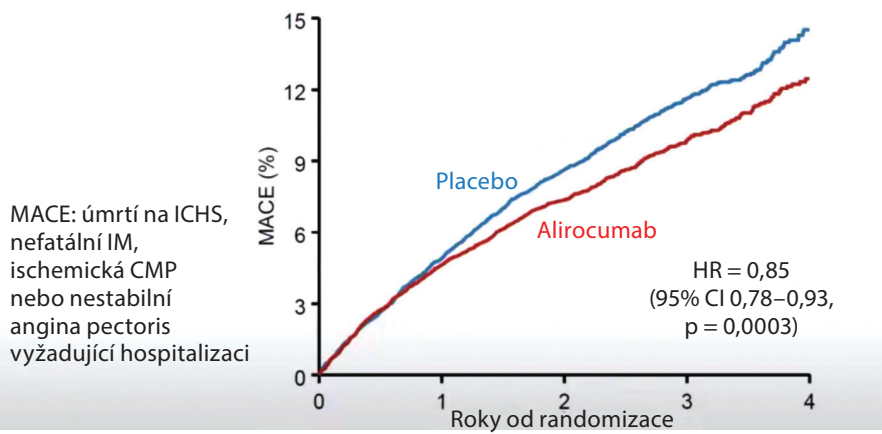

Na přelomu února a března 2021 prodělal pacient infekci covid-19 s lehkým průběhem a na konci března se u něj po návratu do zaměstnání poprvé v životě objevila bolest na hrudi, která byla klidová a výrazná Rychlá záchranná služba jej převezla do kardiocentra, kde byl zjištěn IM přední stěny s elevací úseku ST a provedena perkutánní koronární intervence $(\mathrm{PCl})$ ramus interventricularis anterior. Pacient byl po 5 dnech hospitalizace propuštěn s předepsanou duální antiagregační léčbou, léčbou ß-blokátorem, ACEl a atorvastatinem ve zvýšené dávce 80 mg.

První ambulantní kontrola v dubnu 2021 ukázala normální krevní tlak (129/77 mm Hg), puls (64/min) i EKG nález s ejekční frakcí levé komory 66\%. Podle stávajících doporučení je třeba zkontrolovat lipidogram za 4-6 týdnů po IM (12). Na 2. ambulantní kontrole v květnu 2021 byla zjištěna hladina LDL-c 2,61 mmol// s dobrou tolerancí statinu. Současná doporučení uvádějí jako cílovou hladinu LDL-c u pacientů v sekundární prevenci s velmi vysokým KV rizikem <1,4 mmol// a snížení nejméně o 50 \% (5). U tohoto pacienta vedla v roce 2019 léčba atorvastatinem v dávce 10 mg ke snížení LDL-c z 5,16 na 3,55 mmol/I a léčba atorvastatinem v dávce 80 mg po IM k poklesu ze 3,22 na 2,61 mmol/l. Jelikož nedosahoval cílového poklesu, bylo podle doporučení indikováno přidání ezetimibu. Při vysoce intenzivní statinové léčbě + léčbě ezetimibem by bylo možné dosáhnout poklesu LDL-c zhruba na 2,1 mmol/l. Ani tato kombinace by tedy k cílové hladině nevedla. Naopak při přidání PCSK9i by bylo u tohoto nemocného možné dosáhnout hladiny $1,3 \mathrm{mmol} / \mathrm{l}$ a při kombinaci vysoce intenzivní statinové léčby + ezetimibu + PCSK9i hladiny 0,8 mmol/I. Podle společného stanoviska odborných společností k podávání PCSK9i je možné u pacientů s hladinou LDL-c o > 50 \% vyšší, než je cílová hodnota, nevyužít ezetimib a pacienta prímo indikovat k podávání PCSK9i (14). Pokud je nevyužití ezetimibu medicínsky zdůvodněno, jsou úhradová kritéria pro PCSK9i splněna.

Nyní je tedy třeba rozhodnout, zda pacienta odeslat do specializovaného centra k léčbě PCSK9i nebo zda nasadit ezetimib.

\section{Je vhodné přidat $\mathbf{k}$ maximální statinové terapii PCSK9i bez využití ezetimibu? prof. MUDr. Aleš Linhart, DrSc. \\ (II. interní klinika kardiologie a angiologie 1. LF UK a VFN Praha)}

Snížením hladiny LDL-c u pacientů s vysokým KV rizikem a nedostatečně kompenzovanou hypercholesterolemií při přidání ezetimibu v porovnání s přidáním alirocumabu k maximální tolerované dávce statinu se zabývala studie ODYSSEY COMBO II. Po 6 měsících léčby bylo u pacientů v rameni s přidáním ezetimibu dosaženo poklesu LDL-c průměrně o 20,7\%, tj. hladiny 2,1 mmol/l, zatímco u pacientů v rameni s přidáním PCSK9i klesl LDL-c průměrně o 50,6\% a jeho hladina činila 1,3 mmol/I. Tento efekt přetrvával i po 1 roce (obr. 3) (15). K dispozici máme i data, která dokládají prínos alirocumabu i u pacientů po prodělání IM nebo CMP. Analýza 9 studií ukázala pokles hladiny LDL-c při léčbě alirocumabem zhruba o 50\% bez ohledu na prodělání KV př́hody (15-22). Z uvedených výsledků vyplývá, že doporučených cílových hodnot LDL-c lze u pacienta s velmi vysokým KV rizikem z výše uvedené kazuistiky $(<1,4 \mathrm{mmol} /)$ dosáhnout pouze kombinací vysoce intenzivní statinové léčby a PCSK9i $(5,15)$.

Kromě snižení hladiny LDL-c je třeba porovnat i vliv léčby na morbiditu a mortalitu. Studie IMPROVE-IT prokázala snížení mortality pacientů po AKS při přidání ezetimibu ke statinové léčbě (simvastatin 40 mg) v porovnání s monoterapií statinem během 7 let o 6,4\% (23). Tento prínos ezetimibu je statisticky významný, ovšem analýzy podskupin ukázaly, že lze doložit pouze u žen, nikoliv u mužů (24) a pouze u diabetiků, nikoliv u pacientů bez diabetu (25). Naopak, jak již bylo uvedeno, alirocumab prokázal ve studii ODYSSEY OUTCOMES snížení mortality u srovnatelné populace pacientů o $15 \%$ (9). Výskyt velkých KV př́hod snížil ve stejné studii rovněž o $15 \%$ (95\% Cl 0,78-0,93, p = 0,0003), (obr. 4) (26). Při hladině LDL-c 2,6 mmol/I Ize tedy u pacientů po AKS dosáhnout snížení mortality o 6,4\% během 7 let při přidání ezetimubu nebo o 15 \% během 4 let při přidání alirocumabu $(23,26)$. Pokles výskytu velkých KV př́hod při snižující se hladině LDL-c byl jasně doložen a také bylo prokázáno, že i u nemocných s velmi vysokým KV rizikem Ize při adekvátním snížení LDL-c dosáhnout nejen zpomalení progrese aterosklerózy, ale i její regrese.

\section{Kazuistika 2: pacient s akutním koronárním syndromem - terapeutické rozhodování prof. MUDr. Petr Oštádal, Ph.D. (Nemocnice Na Homolce, Praha)}

U výše popsaného 55letého muže po STEMI, u kterého je při léčbě atorvastatinem $80 \mathrm{mg}$ dosaženo hladiny LDL-c 2,61 mmol//, je adekvátním postupem intenzifikace hypolipidemické léčby. Rozhodovat se mưžeme mezi nasazením ezetimibu nebo PCSK9i. Nasazení ezetimibu u takovéhoto 


\section{NOVINKY V KARDIOLOGII}

PRO A PŘEDEM PROHRANÝ SOUBOJ PROTI PCSKG INHIBITORÜM

Obr. 5. Podíl pacientů po AKS s dosažením cillové hodnoty LDL cholesterolu (LDL-c) prì pridáni alirocumabu k intenzivní statinové léčbě podle vstupni hladiny LDL-c ve studii ODYSSEY OUTCOMES (28)

\section{Dosažení hladiny LDL-c $<1,4 \mathrm{mmol} / /$}

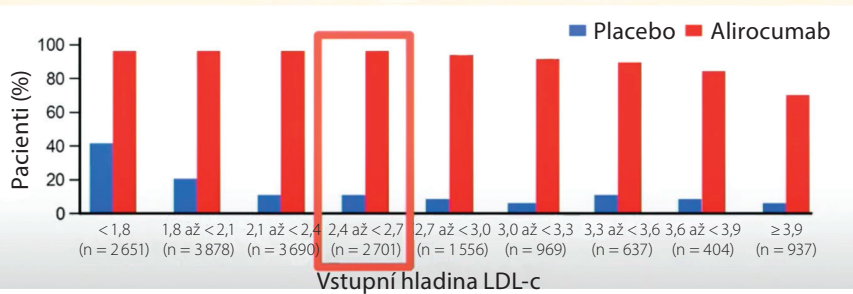

Obr. 6. Snižení rizika velkých kardiovaskulárních príhod (MACE) a celkové mortality u pacientů po AKS při pridání alirocumabu k intenzivní statinové léčbě v závislosti na vstupní hladině $L D L$ cholesterolu (LDL-c) ve studii ODYSSEY OUTCOMES (26)
A

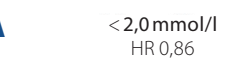
$(95 \%$ Cl $0,74-1,0)$

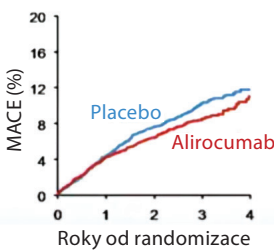

B

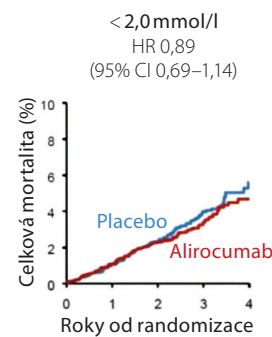

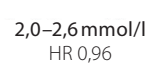
$\begin{array}{rl}H R & 0,96 \\ & 95 \% \text { CI } 0,82-1,14)\end{array}$
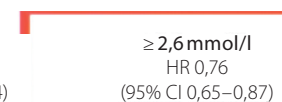
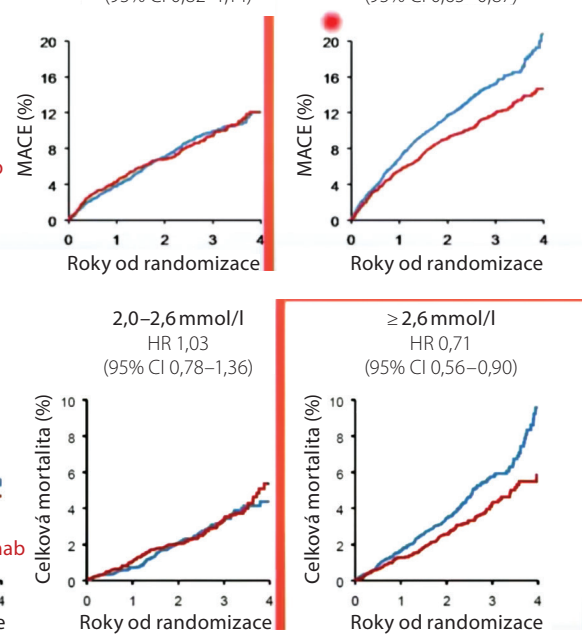

pacienta odpovídá sice aktuálním doporučením, ale vede průměrně ke snížení hladiny LDL-c pouze o 22,7\% (13), čímž by u tohoto nemocného nebylo dosaženo cílové hladiny $<1,4 \mathrm{mmol} / \mathrm{l}$. Navíc by při nasazení ezetimibu a poklesu LDL-c pod 2,5 mmol// pacient již dále nesplňoval úhradová kritéria pro PCSK9i. Přidání ezetimibu danému pacientovi také s největší pravděpodobností nezlepší prognózu. Ve studii IMPROVE-IT (23) bylo nasazením ezetimibu po AKS sníženo riziko KV př́hody za 7 let o pouhých 6,4\%. Navíc prínos ezetimibu byl pozorován pouze v podskupině pacientů, kteří měli nejméně 3 další rizikové faktory zahrnující srdeční selhání, hypertenzi, diabetes, věk nad 75 let, CMP, CABG, periferní aterosklerózu, odhadovanou glomerulární filtraci (eGFR) <60 ml/min nebo kouření (27). Pacient z popsané kazuistiky má pouze 1 z uvedených rizikových faktorů - hypertenzi. Naopak prínos PCSK9i je pacientů s uvedenými charakteristikami dobře doložen. Podle výsledků studie ODYSSEY OUTCOMES by měl pacient z této kazuistiky se vstupní hladinou LDL-c v rozmezí 2,4-2,7 mmol// po přidání alirocumabu 97\% pravděpodobnost dosažení cílové hladiny LDL-c <1,4 mmol/l (obr. 5) (28) a tato léčba by u něj

\section{LITERATURA}

1. Freiberger T, Vaclová M, Tichý L, et al. Familiární hypercholesterolemie v České republice $\checkmark$ roce 2016. Vnitr Lek 2016; 62(11): 924-928.

2. Vrablík M, Vaclová M, Tichý L, et al. Familial hypercholesterolemia in the Czech Republic: more than 17 years of systematic screening within the MedPed project. Physiol Res 2017; 66(Suppl 1): S1-S9.

snížila riziko velkých KV príhod o 24\% (HR = 0,76, 95\% Cl 0,65-0,87) (obr 6A) a celkovou mortalitu o 29\% (HR=0,71, 95\% Cl0,56-0,90) (obr. 6B) (26)

Přestože se mưže zdát, že popsaný pacient nesplňuje úhradové kritérium pro PCSK9i (tj. hladina LDL-C $\geq 2,5$ mmol/I při maximální tolerované dávce statinu a podávání ezetimibu), umožňují podmínky úhrady podávat PCSK9i i bez využití ezetimibu v rámci hypolipidemické léčby, pokud je to medicínsky odůvodněné. U tohoto nemocného Ize nevyužití ezetimibu snadno odůvodnit tím, že při této léčbě nelze předpokládat dosažen léčebného cíle (LDL-c $<1,4 \mathrm{mmol} / \mathrm{I}$ ) a vzhledem k rizikovému profilu a komorbiditám pacienta ani zlepšení prognózy.

Pacient je léčen atorvastatinem v maximální dávce 80 mg, což je statin s nejlepšími důkazy u pacientů po AKS. Přidání ezetimibu by pro něj pravděpodobně nebylo prínosem z hlediska dosažení cílové hladiny LDL-c ani zlepšení prognózy. Splňuje úhradové podmínky pro nasazení PCSK9i, což bude u něj nejvhodnějším postupem intenzifikace hypolipidemické léčby.

\section{Kazuistika 1: pacient s hereditární familiární hypercholesterolemií - závěr prof. MUDr. Vladimír Blaha, CSc. (LF UK a FN Hradec Králové)}

Výše popsaný pacient s heterozygotní FH a diabetem 2. typu léčený od roku 2005 kombinací atorvastatinu 80 mg + ezetimibu 10 mg + LDL aferézy měl stále neuspokojivě kompenzovaný lipidogram (TC 5,13 mmol/l, LDL-c 3,56 mmol/I a TG 2,03 mmol/I). V roce 2019 ve věku 63 let u něj byla přitomna také ischemická choroba dolních končetin a diabetická nefropatie. Jakmile to bylo možné, byl mu nasazen alirocumab v dávkování 150 mg s. c. 1×za 2 týdny. Pomocí této léčby se podařilo dosáhnout hladiny LDL-c 1,4 mmol/l, TC činil 3,37 mmol/l a TG 2,81 mmol/I. V roce 2021 je pacient ve věku 65 let stále bez akutního KV onemocnění.

\section{Závěr}

Jak vyplynulo z prezentací, vzácnější formy dyslipidemií nejsou vzácné a nepoznané mohou mít pro pacienta fatální následky. Dále, u pacientů po IM s vysokým KV rizikem je třeba rychle dosáhnout cílové hladiny LDL-c pod 1,4 mmol/l, a to $v$ indikovaných případech i časným nasazením PCSK9i (při splnění úhradových kritérií). Alirocumab je velmi účinný PCSK9 inhibitor s možností volby individuální dávky, který vede k 50-60\% snížení LDL-c oproti výchozím hodnotám. U těchto pacientů je třeba také intenzivně léčit průvodní choroby, které jsou zásadní pro prognózu pacienta, jako je hypertenze, diabetes, renální insuficience, chronická obstrukční plicní nemoc (CHOPN) či obstrukční spánková apnoe. Nezbytnou součástí moderní léčby je mezioborová spolupráce se vzájemnou komunikací, výměnou dat a zkušeností mezi lékaři.

Připravila MUDr. Zuzana Zafarová

3. Li S, Zhang HW, Guo YL, et al. Familial hypercholesterolemia in very young myocardial in farction. Sci Rep 2018; 8(1): 8861.

4. Khera AV, Won HH, Peloso GM, et al. Diagnostic Yield and Clinical Utility of Sequencing Familial Hypercholesterolemia Genes in Patients With Severe Hypercholesterolemia. J Am Col Cardiol 2016; 67(22): 2578-2589. 


\section{INZERCE}




\section{NOVINKY V KARDIOLOGII}

PRO A PŘEDEM PROHRANÝ SOUBOJ PROTI PCSK9 INHIBITORÜM

5. Mach F, Baigent C, Catapano AL, et al. ESC Scientific Document Group. 2019 ESC/EAS Gu idelines for the management of dyslipidaemias: lipid modification to reduce cardiovascular risk. Eur Heart J 2020; 41(1): 111-188.

6. Vrablik M, Raslová K, Vohnout B, et al. Real-life LDL-C treatment goals achievement in patients with heterozygous familial hypercholesterolemia in the Czech Republic and Slovakia: Results of the PLANET registry. Atherosclerosis. 2018; 277: 355-361.

7. Raal FJ, Stein EA, Dufour R, et al. RUTHERFORD-2 Investigators. PCSK9 inhibition with evolocumab (AMG 145) in heterozygous familial hypercholesterolaemia (RUTHERFORD-2): a randomised, double-blind, placebo-controlled trial. Lancet. 2015; 385(9965): 331-340.

8. Kastelein JJ, Ginsberg HN, Langslet G, et al. ODYSSEY FH I and FH II: 78 week results with alirocumab treatment in 735 patients with heterozygous familial hypercholesterolaemia. Eur Heart J. 2015; 36(43): 2996-3003.

9. Steg PG, Szarek M, Bhatt DL, et al. Effect of Alirocumab on Mortality After Acute Coronary Syndromes. Circulation 2019; 140(2): 103-112.

10. Sanders DW, Jumper CC, Ackerman PJ, et al. SARS-CoV-2 requires cholesterol for viral entry and pathological syncytia formation. Elife. 2021; 10: e65962.

11. Zhang XJ, Qin JJ, Cheng X, et al. In-Hospital Use of Statins Is Associated with a Reduced Risk of Mortality among Individuals with COVID-19. Cell Metab 2020; 32(2): 176-187.e4.

12. Oštádal P, Táborský M, Lihart A, et al. Stručný souhrn doporučení pro dlouhodobou péč o nemocné po infarktu myokardu. Cor et Vasa 2019; 61(5): 471-480.

13. Cannon CP, Khan I, Klimchak AC, et al. Simulation of Lipid-Lowering Therapy Intensification in a Population With Atherosclerotic Cardiovascular Disease. JAMA Cardiol 2017; 2(9): 959-966. 14. Češka R, Táborský M, Vrablík M. Společné stanovisko odborných společností k předepisování inhibitorů PCSK9. AtheroRev. 2018; 3(3): 201-207.

15. Cannon CP, Cariou B, Blom D, et al. ODYSSEY COMBO II Investigators. Efficacy and safety of alirocumab in high cardiovascular risk patients with inadequately controlled hypercholesterolaemia on maximally tolerated doses of statins: the ODYSSEY COMBO I| randomized controlled trial. Eur Heart J. 2015; 36(19): 1186-1194.

16. Furie KL, Kasner SE, Adams RJ, et al. American Heart Association Stroke Council, Council on Cardiovascular Nursing, Council on Clinical Cardiology, and Interdisciplinary Council on Quality of Care and Outcomes Research. Guidelines for the prevention of stroke in patients with stroke or transient ischemic attack: a guideline for healthcare professionals from the american heart association/american stroke association. Stroke 2011; 42(1): 227-276.

17. Kotseva K, Wood D, De Bacquer D, et al. EUROASPIRE Investigators. EUROASPIRE IV: A European Society of Cardiology survey on the lifestyle, risk factor and therapeutic management of coronary patients from 24 European countries. Eur J Prev Cardiol. 2016; 23(6): 636-648 18. Bruckert E, Hayem G, Dejager S, et al. Mild to moderate muscular symptoms with high-dosage statin therapy in hyperlipidemic patients--the PRIMO study. Cardiovasc Drugs Ther 2005: 19(6): 403-414.

19. Banegas JR, López-García E, Dallongeville J, et al. Achievement of treatment goals for primary prevention of cardiovascular disease in clinical practice across Europe: the EURIKA study. Eur Heart J. 2011; 32(17): 2143-2152.

20. Roth EM, Taskinen MR, Ginsberg HN, et al. Monotherapy with the PCSK9 inhibitor alirocumab versus ezetimibe in patients with hypercholesterolemia: results of a 24 week, double-blind, randomized Phase 3 trial. Int J Cardiol. 2014; 176(1): 55-61.

21. Koren MJ, Roth EM, McKenney JM, et al. Safety and efficacy of alirocumab $150 \mathrm{mg}$ every 2 weeks, a fully human proprotein convertase subtilisin/kexin type 9 monoclonal antibody: A Phase II pooled analysis. Postgrad Med 2015; 127(2): 125-132.

22. Robinson JG, Farnier M, Krempf M, et al. ODYSSEY LONG TERM Investigators. Efficacy and safety of alirocumab in reducing lipids and cardiovascular events. N Engl J Med 2015; 372(16): 1489-1499.

23. Cannon CP, Blazing MA, Giugliano RP, et al. IMPROVE-IT Investigators. Ezetimibe Added to Statin Therapy after Acute Coronary Syndromes. N Engl J Med. 2015; 372(25): 2387-2397.

24. Kato ET, Cannon CP, Blazing MA, et al. Efficacy and Safety of Adding Ezetimibe to Statin Therapy Among Women and Men: Insight From IMPROVE-IT (Improved Reduction of Outcomes: Vytorin Efficacy International Trial). J Am Heart Assoc. 2017; 6(11): e006901.

25. Giugliano RP, Cannon CP, Blazing MA, et al. IMPROVE-IT (Improved Reduction of Outcomes: Vytorin Efficacy International Trial) Investigators. Benefit of Adding Ezetimibe to Statin Therapy on Cardiovascular Outcomes and Safety in Patients With Versus Without Diabetes Mellitus: Results From IMPROVE-IT (Improved Reduction of Outcomes: Vytorin Efficacy International Trial). Circulation. 2018; 137(15): 1571-1582.

26. Schwartz GG, Steg PG, Szarek M, et al. ODYSSEY OUTCOMES Committees and Investigators. Alirocumab and Cardiovascular Outcomes after Acute Coronary Syndrome. N Engl Med 2018; 379(22): 2097-2107.

27. Bohula EA, Morrow DA, Giugliano RP, et al. Atherothrombotic Risk Stratification and Ezetimibe for Secondary Prevention. J Am Coll Cardiol 2017; 69(8): 911-921.

28. Landmesser U, Pirillo A, Farnier M, et al. Lipid-lowering therapy and low-density lipoprotein cholesterol goal achievement in patients with acute coronary syndromes: The ACS patient pathway project. Atheroscler Suppl. 2020; 42: e49-e58.

\section{INZERCE}

